\title{
Optimization of Processing Conditions of Traditional Cured Tuna Loins-Muxama
}

\author{
Eduardo Esteves 1,2,* (iD) and Jaime Aníbal 1,3 \\ 1 Departamento de Engenharia Alimentar, Instituto Superior de Engenharia, Universidade do Algarve, \\ 8005-139 Faro, Portugal; janibal@ualg.pt \\ 2 CCMAR, Centro de Ciências do Mar do Algarve, Universidade do Algarve, 8005-139 Faro, Portugal \\ 3 CIMA-Centro de Investigação Marinha e Ambiental, Universidade do Algarve, 8005-139 Faro, Portugal \\ * Correspondence: eesteves@ualg.pt; Tel.: +351-289-800-900
}

Received: 11 November 2017; Accepted: 5 January 2018; Published: 9 January 2018

\begin{abstract}
Muxama is a traditional highly-valued food product prepared from dry-cured tuna loins in southern Portugal and Spain. The production procedure has seen little change over the last centuries. The muxama's stability is due to reduced water activity. In addition, the drying method has secondary effects on characteristics of flavor, color, and the nutritional value of the product. Our objectives were to describe the dynamics of important physicochemical parameters such as moisture content, water activity ( $\mathrm{a}_{\mathrm{W}}$ ), $\mathrm{NaCl}$ concentration (as water-phase salt, $\mathrm{Z}^{\mathrm{NaCl}}$ ), $\mathrm{pH}$ and color, during the salting and drying stages of muxama production, and to test the effect(s) of changes in the traditional processing conditions followed in southern Portugal, aiming at optimizing the production procedure. The lowest values of moisture and $\mathrm{a}_{\mathrm{W}}$ and highest $\mathrm{Z}^{\mathrm{NaCl}}$ obtained after drying tuna loins for seven days at $20^{\circ} \mathrm{C}$ exceeded the values reported for commercial products and have impact on the appearance (color) of the product. Therefore, drying tuna loins at lower temperatures $\left(\mathrm{ca} .14^{\circ} \mathrm{C}\right.$ ) is probably more appropriate. The results obtained in this study could be used in the design of future experiments at other conditions and to assess other quality parameters, e.g., total volatile base nitrogen (TVB-N), thiobarbituric acid reactive substances (TBA-RS), microorganism abundance and sensory attributes, and subsequent validation trials.
\end{abstract}

Keywords: muxama; salted-dried tuna loins; physicochemical parameters; statistical modelling

\section{Introduction}

Muxama (in Portugal), or mojama (in Spain), is a traditional, highly valued food product prepared from dry-cured tuna loins that is a delicatessen in the southern Iberian Peninsula: Algarve (Portugal) and Andalucía, Murcia, Alicante and Valencia (Spain). Its production process is slightly different among locations. These differences supported the application and recent registration of two Protected Geographical Indications (PGI), Mojama de Barbate [1] and Mojama de Isla Cristina [2], within the European Union's quality schemes for agricultural products and foodstuffs [3] by two municipalities in Andalucia (Spain), namely Barbate and Isla Cristina. Muxama is one of numerous food products that can be obtained from a tuna at the end of the (traditional) quartering of specimens a.k.a. "ronqueamento" (or "ronqueo") [4-6].

Succinctly, the tuna (mostly Thunnus obesus and T. albacares) loins are salted and dried according to a predominantly artisanal procedure that incorporates empirical knowledge passed down numerous generations since at least the tenth century [6] or even earlier. According to [4,5], native Iberians were already drying and salting fish, particularly tuna, in pre-Roman times (earlier than the second century B.C.) and during Roman rule over Hispania (until the fourth century). The practice was further developed by the Arabs during Al-Andalus (in the eighth and ninth centuries) $[7,8]$. The preparation of muxama involves a series of steps that are described in $[4,6,7]$ and more recently in [9]. The production 
process changed little over the years but today the tuna used in the production of muxama is fished elsewhere and arrives frozen to the plants $[4,10]$ instead of being fished using an "armação" (or "almadrava"), an off-shore maze of bottom-fixed nets to imprison, capture and hold the fish [11].

Drying is one of the earliest known means of preserving food [12-14], namely fish and other seafood. A preparatory dry salting or brining stage usually precedes it and the stability of the end-product derives from the reduced water activity and, in some products, lowered $\mathrm{pH}$. In addition, the drying method has secondary effects on characteristics of flavor, color, and the nutritional value of the products $[14,15]$. A number of authors have studied and/or reviewed the salting and drying process of fish and other seafood and its effects on various quality parameters of the final products, e.g., [13,16-25]. In what concerns muxama, Barat and Grau [10] observed a clear shortening of the processing time required to obtain muxama with the simultaneous brine thawing and salting of frozen tuna loins.

Our objectives were to describe the dynamics of important physical-chemical parameters such as moisture content, water activity $\left(\mathrm{a}_{\mathrm{W}}\right), \mathrm{NaCl}$ concentration (as water-phase salt and ratio of $\mathrm{NaCl}$ incorporation during drying), $\mathrm{pH}$ and color, during the salting and drying stages of muxama production and to test the effect(s) of changes in the traditional processing conditions followed in southern Portugal (Algarve), aiming at optimizing the production procedure.

\section{Results}

In Experiment I, the incorporation of salt in tuna loins was accompanied by water loss (Figure 1a-c). Notwithstanding, the patterns of these processes along the salting period were quite different for the outer, exterior (Ext.) portions when compared to the center, interior (Int.) portions. Differences were more prominent for the diffusion of $\mathrm{NaCl}$ that followed a sigmoidal, logistic model in the case of interior portions instead of the expected hyperbolic behavior of Fickian diffusion processes found in exterior portions of the loins (Figure 1a). Initially, salt was incorporated and water was diffused out of the loins at higher rates in the case of exterior portions (Figure 1a,b). In contrast, the distance corresponding to the outer portion is responsible for a delay in the increase of water-phase salt $\left(Z^{\mathrm{NaCl}}\right)$, about $10 \mathrm{~h}$ (Figure 1a). These changes in $\mathrm{Z}^{\mathrm{NaCl}}$ were statistically modelled using the Zugarramurdi and Lupin [26] model for the exterior portions and the three-parameter logistic model for the interior portions (Table 1). In addition, the final $\mathrm{NaCl}$ concentration was higher and the moisture content and water activity were substantially lower for exterior portions than for interior portions of the loins (Figure 1a-c). 


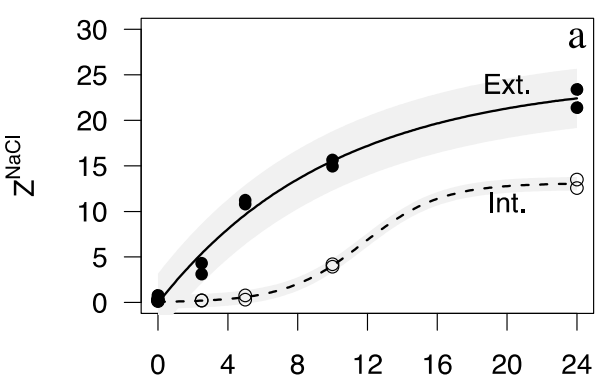

Time (h)

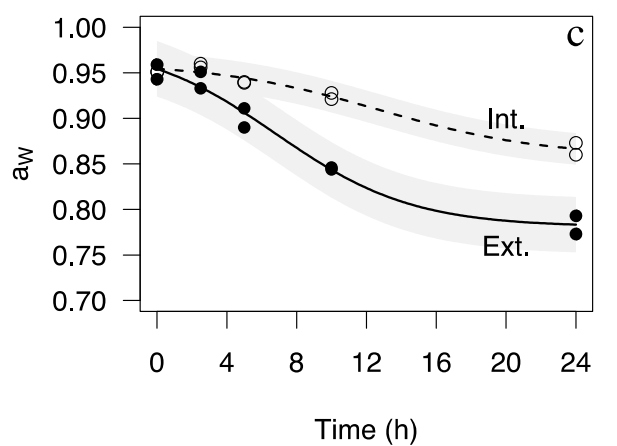

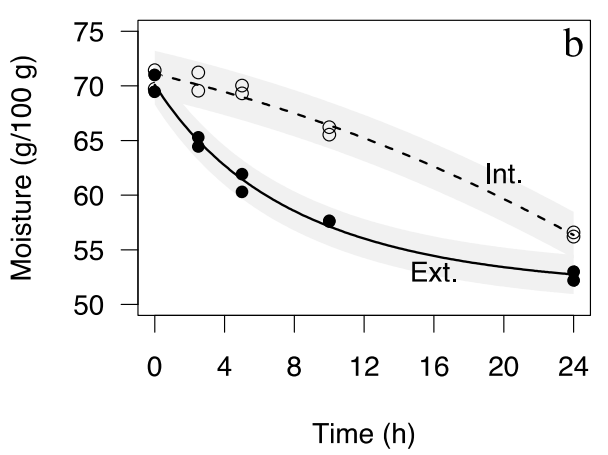

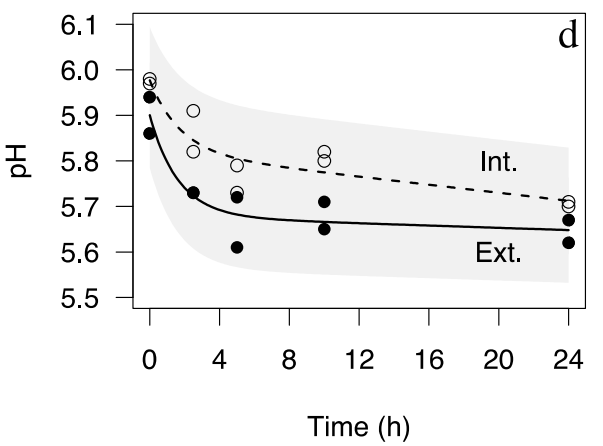

Figure 1. Changes in (a) $\mathrm{NaCl}$ concentration (as water-phase salt concentration $\mathrm{Z}^{\mathrm{NaCl}}$ ); (b) moisture content; (c) water activity ( $\mathrm{a}_{\mathrm{W}}$ ) and (d) $\mathrm{pH}$ in the interior (Int., empty circles $\mathrm{O}$ and dotted line --) and exterior (Ext., filled circles $\bullet$ and continuous line - ) portions of tuna loins along the $24 \mathrm{~h}$ period of salting. Lines depict the models described in Table 1 and shaded areas correspond to $95 \%$ confidence intervals.

Table 1. Mathematical models fitted to the parameters $(y)$ for exterior and interior portions of tuna loins during salting experiment.

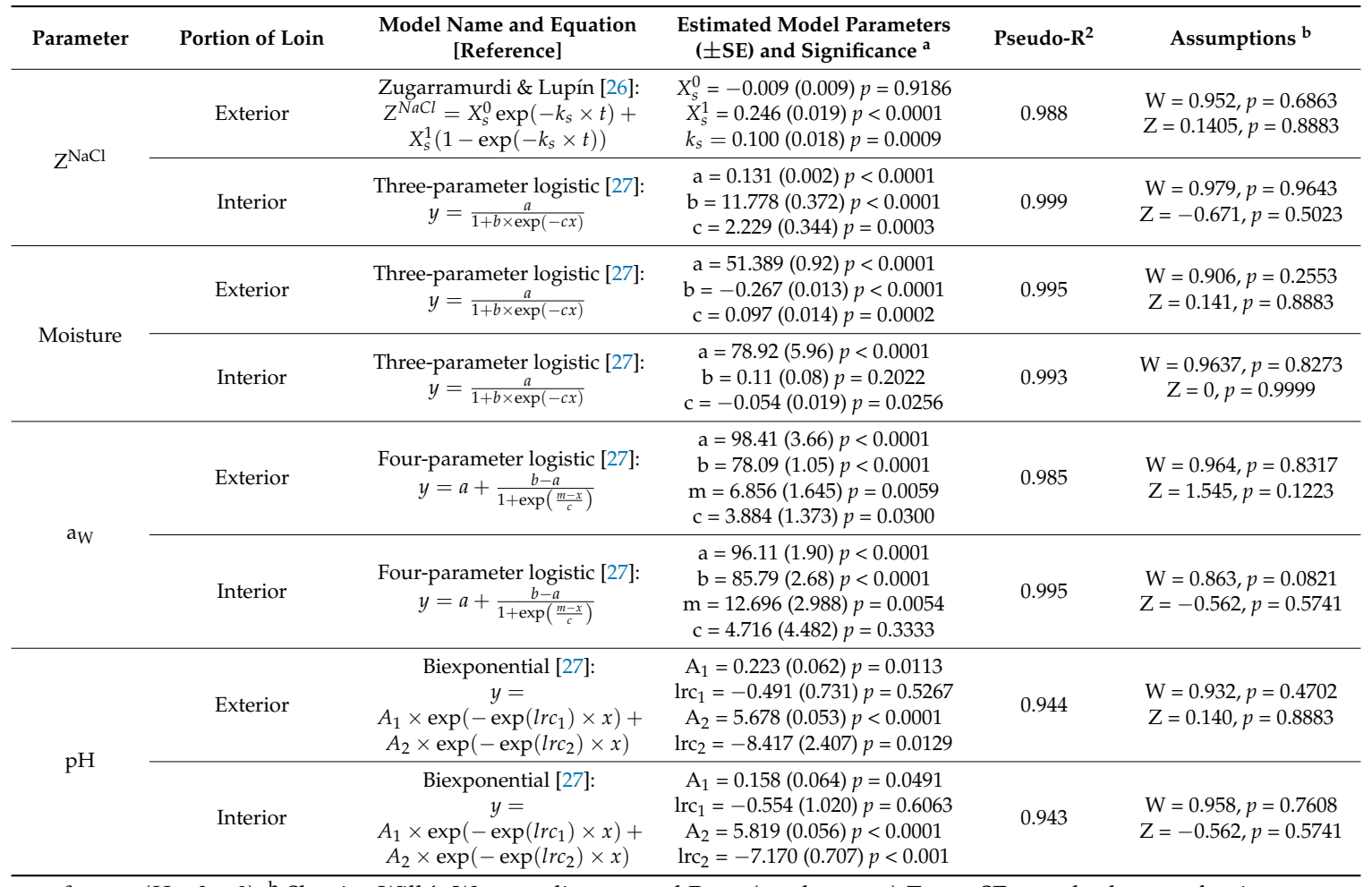

\footnotetext{
${ }^{\mathrm{a}} t$-test $\left(H_{0}: \theta=0\right){ }^{\mathrm{b}}$ Shapiro-Wilk's W normality test and Runs (randomness) $\mathrm{Z}$ test. SE: standard error of estimate.
} 
Changes in portions' $\mathrm{pH}$ were readily visible and displayed a similar behavior but were slightly higher in the interior portions throughout the salting period (Figure 1). A two-compartment exponential model fitted the data for exterior and interior portions of "loins" during salting (Table 1). Generally, the $\mathrm{pH}$ decreased along the experiment, especially during the first hours of salting.

The physical-chemical changes related to the diffusive processes of salt intake and water loss were accompanied by changes in appearance, namely color (Figure 2), that were similar in exterior and interior portions of tuna loins in terms of plain $\mathrm{L}^{*}, \mathrm{a}^{*}$ and $\mathrm{b}^{*}$ but not in terms of composite color parameters, particularly chroma and saturation. Despite the observed variability, values of $L^{*}$ and $a^{*}$ decreased in interior portions of loins whilst they remained stable in exterior portions. In addition, the changes in chroma and saturation were more obvious in interior portions, which peaked after about 12-16 h salting time.

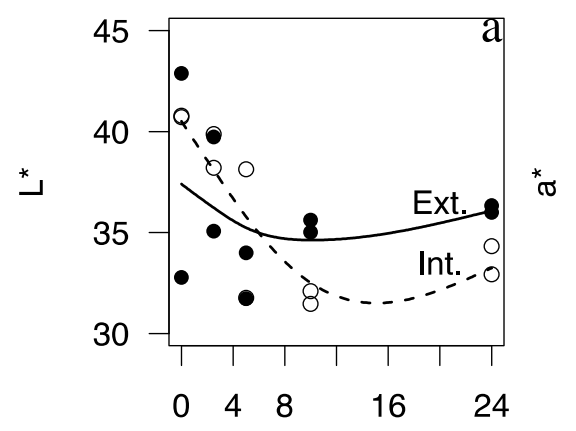

Time (h)

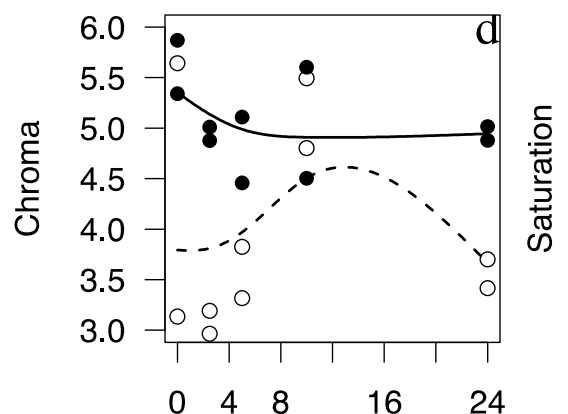

Time (h)



Time (h)

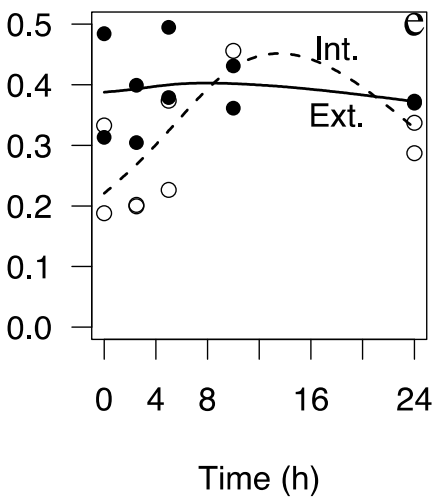

Figure 2. Changes in color $(\mathbf{a}-\mathbf{c})$ Commission Internationale de l'Éclairage CIE $\mathrm{L}^{*} \mathrm{a}^{*} \mathrm{~b}^{*}$ and derived parameters: (d) Chroma; (e) Saturation; and (f) Hue angle in the interior (Int., empty circles $\circ$ and dotted line --) and exterior (Ext., filled circles $\bullet$ and continuous line -) portions of tuna loins along the $24 \mathrm{~h}$ period of salting. Non-parametric smoothing curves (splines) are shown for illustrative purposes only.

When studying the drying stage of the traditional process of producing muxama (Experiment II), data on moisture, $\mathrm{a}_{\mathrm{W}}, \mathrm{NaCl}$ content (as $\mathrm{Z}^{\mathrm{NaCl}}$ and ratio of $\mathrm{NaCl}$ incorporation during drying, $\mathrm{R}^{\mathrm{NaCl}}$ ), and color (Commission Internationale de l'Éclairage CIE L*a* $\mathrm{b}^{*}$ and derived parameter) was also obtained at important milestones: fresh, raw material; just after salting; and following the drying stage.

Moisture and water activity decreased from $59.53 \mathrm{~g} \cdot 100 \mathrm{~g}^{-1}\left( \pm 4.02 \mathrm{~g} \cdot 100 \mathrm{~g}^{-1}\right)$ and $0.971( \pm 0.034)$, respectively, in fresh tuna loins to $48.74 \mathrm{~g} \cdot 100 \mathrm{~g}^{-1}\left( \pm 3.04 \mathrm{~g} \cdot 100 \mathrm{~g}^{-1}\right)$ and $0.759( \pm 0.007)$ in loins after $24 \mathrm{~h}$ dry salting. In contrast, the water-phase $\mathrm{NaCl}$ content $\left(Z^{\mathrm{NaCl}}\right)$ increased from negligible value of 0.0003 to about 0.21 just after salting (i.e., $0.06 \mathrm{~g} \cdot 100 \mathrm{~g}^{-1}$ to $11.7 \mathrm{~g} \cdot 100 \mathrm{~g}^{-1}$ ). In terms of color, CIE $\mathrm{L}^{*} \mathrm{a}^{*} \mathrm{~b}^{*}$ parameters were $L^{*}=37.8( \pm 0.58), a^{*}=5.16( \pm 0.66)$ and $b^{*}=1.87( \pm 0.57)$ for fresh loins and $L^{*}=36.2$ 
$( \pm 0.71), a^{*}=5.01( \pm 0.71)$ and $b^{*}=-0.59( \pm 0.79)$ for salted loins. The further effects of temperature (14 and $20^{\circ} \mathrm{C}$ ) and time (four and seven days) of the subsequent drying stage on those parameters and other, derived parameters were studied in the context of a two-level factorial experiment. The analysis of variance (ANOVA) results are compiled in Table 2.

Table 2. Analysis of variance (ANOVA) results of two-level factorial experiments carried out to study the effects of time (four and seven days) and temperature $\left(14\right.$ and $\left.20^{\circ} \mathrm{C}\right)$ of drying on various parameters of muxama.

\begin{tabular}{|c|c|c|c|c|}
\hline Parameter & Factor $^{\text {a }}(\mathrm{X})$ & $\mathbf{F}$ & $p$ & Model $^{\text {b }}$ (Adjusted $R^{2}$ vs. Predicted $R^{2}$ ) \\
\hline Moisture & Time $(t)$ & 4.95 & 0.0901 & Moisture $=49.67-1.03 t-0.83 T$ \\
\hline \multirow[t]{2}{*}{$\left(\mathrm{g} \cdot 100 \mathrm{~g}^{-1}\right)$} & $\begin{array}{c}\text { Temperature } \\
(T)\end{array}$ & 12.70 & $0.0235 *$ & (0.7296 vs. 0.5056$)$ \\
\hline & $t \times T$ & 0.22 & 0.6608 & \\
\hline Water activity & $t$ & 23.05 & $0.0086^{* *}$ & $\mathrm{a}_{\mathrm{W}}=0.68+97 \times 10^{-3} t+3.9 \times 10^{-3} \mathrm{~T}-8.6 \times 10^{-4} t \times \mathrm{T}$ \\
\hline \multirow[t]{2}{*}{$\left(a_{w}\right)$} & $T$ & 2.39 & 0.1970 & (0.8045 vs. 0.5532$)$ \\
\hline & $t \times T$ & 6.36 & 0.0652 & \\
\hline \multirow[t]{3}{*}{$\mathrm{Z}^{\mathrm{NaCl}}$} & $t$ & 11.84 & $0.0263 *$ & $\mathrm{Z}^{\mathrm{NaCl}}=-0.108-0.010 t+9.27 \times 10^{-5} T$ \\
\hline & $T$ & 38.92 & $0.0034^{* *}$ & $(0.8335$ vs. 0.6956$)$ \\
\hline & $t \times T$ & 2.85 & 0.1666 & \\
\hline \multirow[t]{3}{*}{$\mathrm{R}^{\mathrm{NaCl}}$} & $t$ & 19.13 & $0.0119 *$ & $\mathrm{R}^{\mathrm{NaCl}}=2.87-0.63 t-0.07 T+0.05 t \times T$ \\
\hline & $T$ & 62.56 & $0.0014^{* *}$ & (0.9255 vs. 0.8296$)$ \\
\hline & $t \times T$ & 8.23 & $0.0455^{*}$ & \\
\hline \multirow[t]{3}{*}{$\mathrm{L}^{*}$} & $t$ & 3.38 & 0.0824 & $\mathrm{~L}^{*}=98.71-11.46 t-3.55 T+0.72 t \times T$ \\
\hline & $T$ & 4.00 & 0.0609 & (0.6450 vs. 0.5355$)$ \\
\hline & $t \times T$ & 31.95 & $<0.0001^{* * *}$ & \\
\hline \multirow[t]{3}{*}{$a^{*}$} & $t$ & 0.09 & 0.7742 & $\mathrm{a}^{*}=4.93$ \\
\hline & $T$ & $<0.01$ & 0.9524 & \\
\hline & $t \times T$ & 2.97 & 0.1001 & \\
\hline \multirow[t]{3}{*}{$\mathrm{b}^{*}$} & $t$ & 1.63 & 0.2166 & $\mathrm{~b}^{*}=32.36-5.83 t-1.92 T+0.36 t \times T$ \\
\hline & $T$ & 0.31 & 0.5842 & (0.4821 vs. 0.3515$)$ \\
\hline & $t \times T$ & 22.47 & $<0.0001^{* * *}$ & \\
\hline \multirow[t]{3}{*}{ Chroma } & $t$ & 1.53 & 0.2300 & $C=25.621-4.30 t-1.35 T+0.26 t \times T$ \\
\hline & $T$ & 2.01 & 0.1715 & $(0.5862$ vs. 0.4819$))$ \\
\hline & $t \times T$ & 32.04 & $<0.0001^{* * *}$ & \\
\hline \multirow[t]{3}{*}{ Saturation $\left(\mathrm{S}_{\mathrm{ab}}\right)$} & $t$ & 0.53 & 0.4757 & $\mathrm{Sab}=0.01-2.0 \times 10^{-3} t-6.8 \times 10^{-4} T+1.2 \times 10^{-4} t \times T$ \\
\hline & $T$ & 0.28 & 0.6039 & $(0.4006$ vs. 0.2494$)$ \\
\hline & $t \times T$ & 17.56 & $0.0005^{* * *}$ & \\
\hline \multirow[t]{3}{*}{ Hue angle $\left(\mathrm{H}_{\mathrm{ab}}\right)$} & $t$ & 0.01 & 0.9443 & $\mathrm{H}_{\mathrm{ab}}=60.36$ \\
\hline & $T$ & 0.002 & 0.9656 & \\
\hline & $t \times T$ & 0.65 & 0.4654 & \\
\hline \multirow[t]{3}{*}{ Color difference $(\Delta \mathrm{E})$} & $t$ & 0.01 & 0.9170 & $\Delta \mathrm{E}=41.76-8.01 t-1.84 T+0.47 t \times T$ \\
\hline & $T$ & 6.41 & $0.0199 *$ & $(0.3807$ vs. 0.2878$)$ \\
\hline & $t \times T$ & 5.88 & $0.0249 *$ & \\
\hline
\end{tabular}

${ }^{a}$ The multiplication/product sign $\times$ represents the interaction effect; ${ }^{b}$ Regression model (in actual values) where $t$ is time and $T$ is temperature. Significance: ${ }^{*}$ for $p<0.05,{ }^{* *}$ for $p<0.01$ and ${ }^{* * *}$ for $p<0.001$.

The ANOVA models' goodness of fit is good, particularly for the chemical variables for which adjusted- $\mathrm{R}^{2}>0.80$, and their predictive power is quite reasonable (the difference between adjustedand predicted- $\mathrm{R}^{2}$ was less than approximately 0.10 , except for $\mathrm{a}_{\mathrm{W}}$ ) considering the simple experiment that originated the data.

Except for $\mathrm{a}^{*}$ and Hue angle $\left(\mathrm{H}_{\mathrm{ab}}\right)$, all other variables were affected by the temperature and the duration of the drying stage (Figures 3 and 4). The combination of high(er) temperature-long(er) time 
contributes to significantly decrease moisture content and $\mathrm{a}_{\mathrm{W}}$ and to increase $\mathrm{NaCl}$ content (in terms of $\mathrm{Z}^{\mathrm{NaCl}}$ and $\mathrm{R}^{\mathrm{NaCl}}$ ). The additive effects of temperature and time were unique to moisture and $\mathrm{Z}^{\mathrm{NaCl}}$.

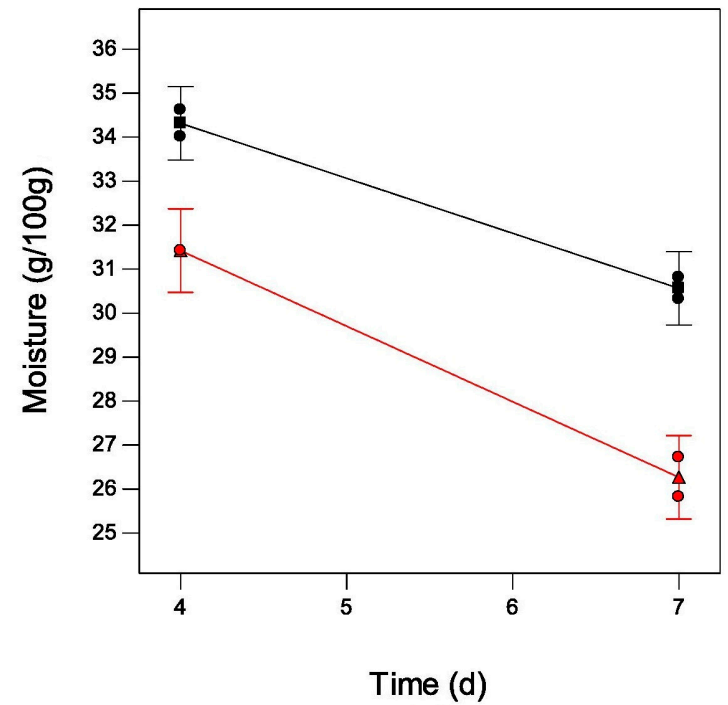

(a)

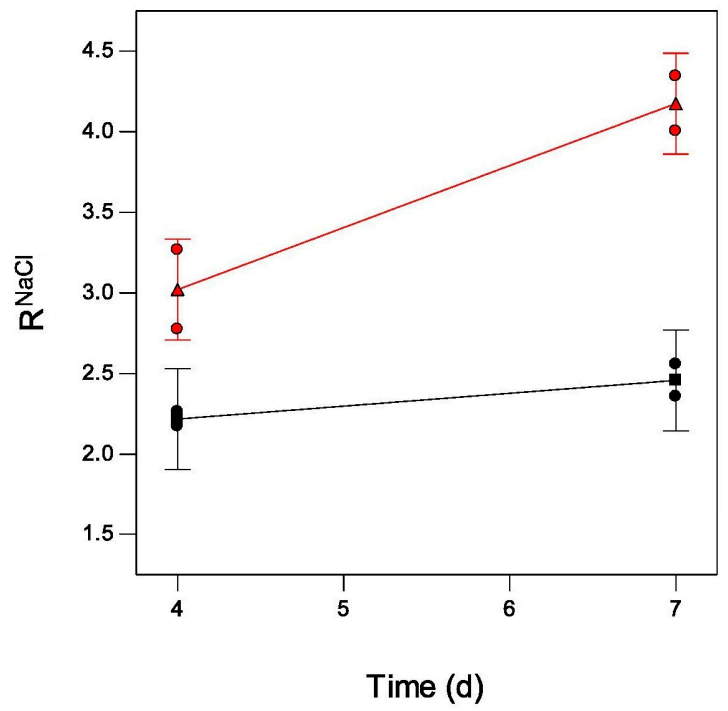

(c)

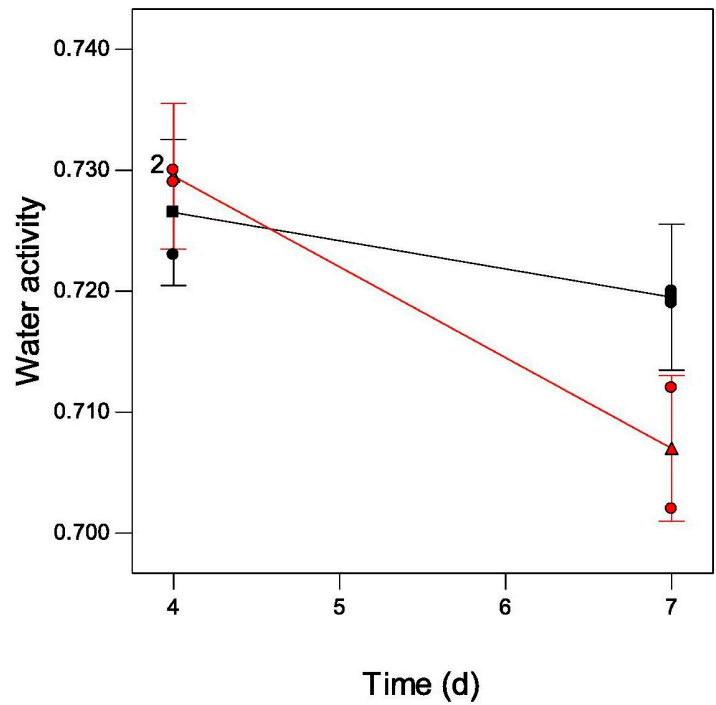

(b)

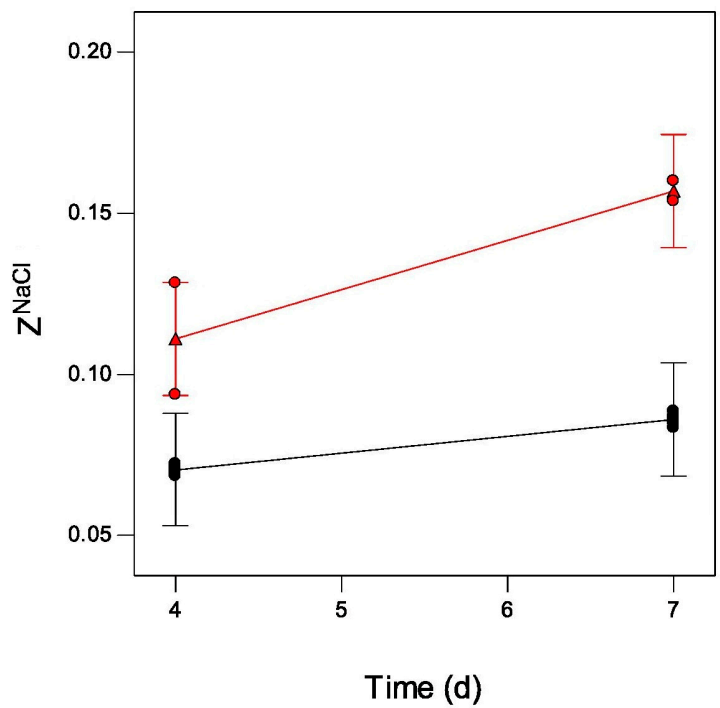

(d)

Figure 3. Interaction plots for (a) moisture; (b) water activity $\left(\mathrm{a}_{\mathrm{W}}\right)$; (c) ratio of $\mathrm{NaCl}$ incorporation during drying $\left(\mathrm{R}^{\mathrm{NaCl}}\right)$; and $(\mathrm{d}) \mathrm{Z}^{\mathrm{NaCl}}$ content of muxama obtained from portions of tuna loins previously dry-salted for $24 \mathrm{~h}$ and dried at 14 or $20^{\circ} \mathrm{C}$ (black squares and red triangles, respectively) for four or seven days (individual data points are presented as filled circles). 


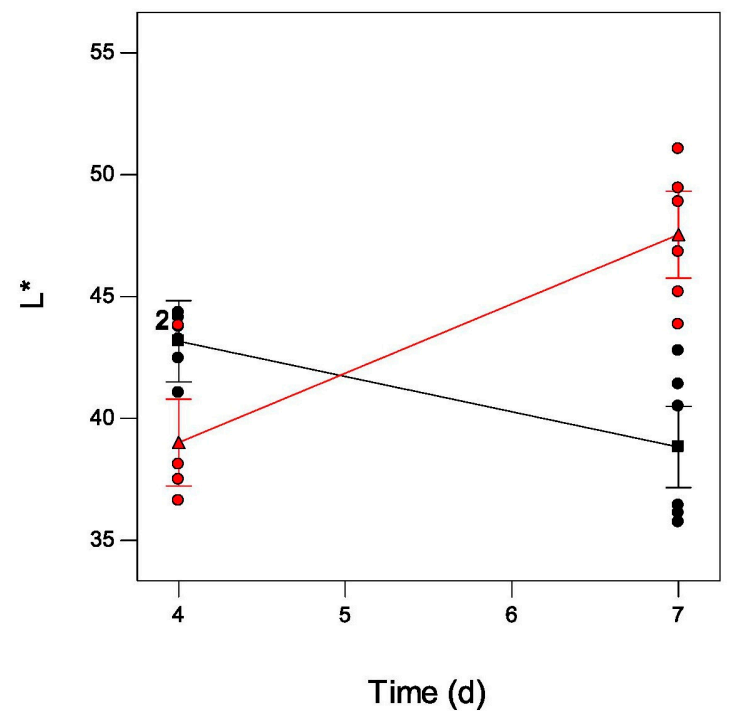

(a)

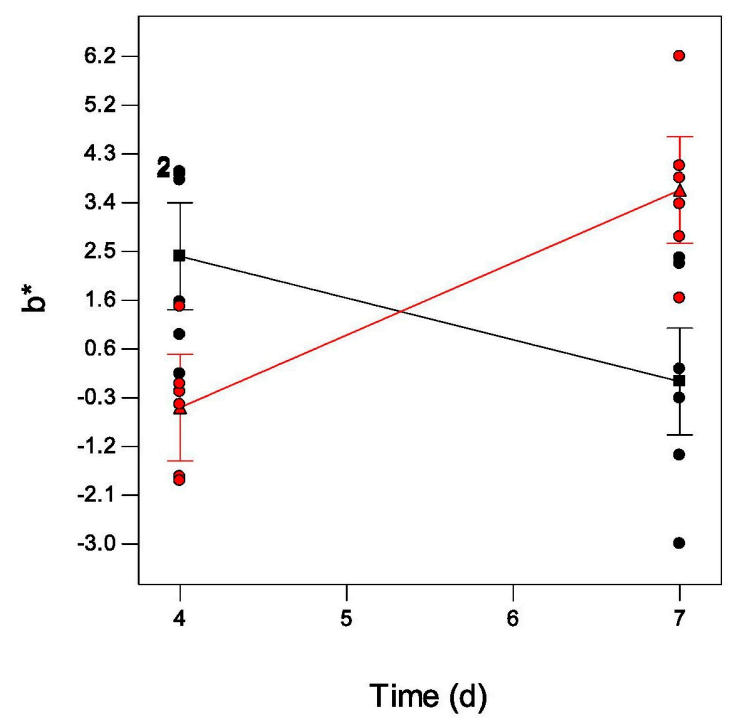

(c)

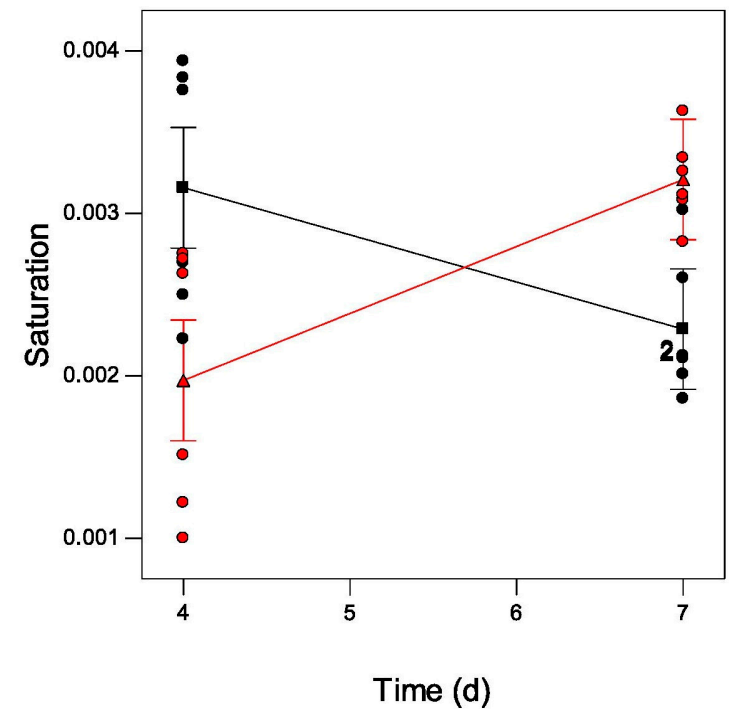

(b)

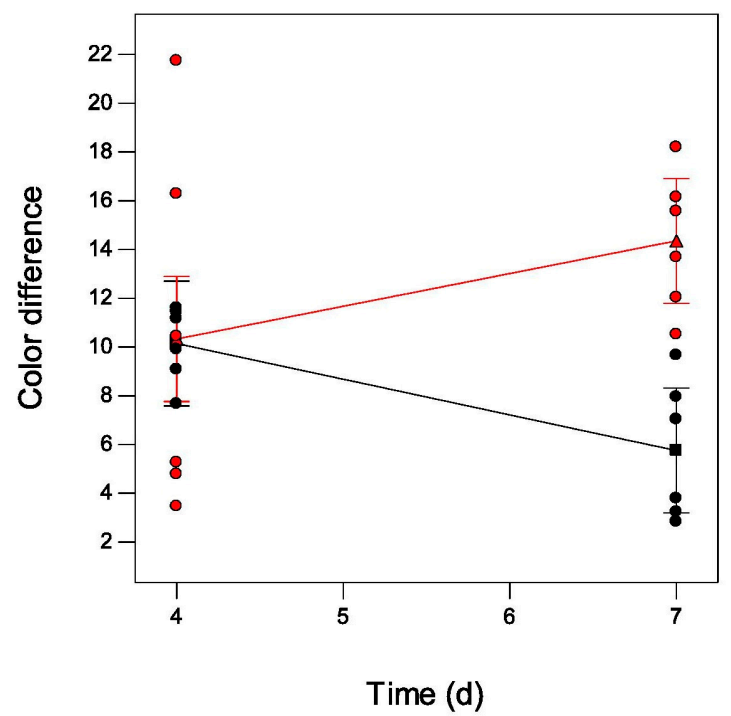

(d)

Figure 4. Interaction plots for color $(\mathbf{a}, \mathbf{c}) \mathrm{CIE} \mathrm{L}^{*}$ and $\mathrm{b}^{*}$ and derived parameters $(\mathbf{b})$ saturation $\left(\mathrm{S}_{\mathrm{ab}}\right)$ and $(\mathrm{d})$ color difference $(\Delta \mathrm{E})$ of muxama obtained from portions of tuna loins previously dry-salted for $24 \mathrm{~h}$ and dried at 14 or $20^{\circ} \mathrm{C}$ (black squares and red triangles, respectively) for four or seven days (individual data points are presented as filled circles).

The moisture content $(H)$ and $\mathrm{a}_{\mathrm{W}}$ at the end of drying were significantly lower $(28-32 \mathrm{~g} \cdot 100 \mathrm{~g}-1$ and $0.70-0.73$, respectively) compared to values obtained just after salting, particularly for loins dried for seven days at $20{ }^{\circ} \mathrm{C}\left(H=26 \mathrm{~g} \cdot 100 \mathrm{~g}^{-1}\right.$ and $\left.\mathrm{a}_{\mathrm{W}}=0.707\right)$.

Moreover, during drying there was a significantly increase the $\mathrm{NaCl}$ content, by 2.5-4-fold the concentration determined after $24 \mathrm{~h}$ salting $\left(\mathrm{R}^{\mathrm{NaCl}}\right)$, mainly in the case of samples dried for 7 days at $20{ }^{\circ} \mathrm{C}$. The final $\mathrm{NaCl}$ concentration (in terms of $\mathrm{Z}^{\mathrm{NaCl}}$ ) was $0.15-0.16$. Temperature and time also affected other variables in a multiplicative way, i.e., there were significant interaction effects. Color changes were readily visible along the drying of loins, that were conveyed in the significant difference found in color difference $(\Delta \mathrm{E})$ and chroma/saturation values among treatments. At higher temperature, the loins were significantly darker after the longer period of drying (seven days) in contrast to what was found for the loins dried only four days. Unexpectedly, no significant changes 
were found for parameter $\mathrm{a}^{*}$, i.e., in terms of redness, with the loins remaining reddish throughout the drying stage.

\section{Discussion}

The incorporation of salt was accompanied, as expected [15], by water loss in Experiment I. In fact, salting is basically a sodium and chloride transport by a diffusion mechanism induced by differences in concentrations and osmotic pressures among inter-cells and salting agent $[10,13]$. Notwithstanding, the observed patterns of these processes were distinct for the exterior and interior portions of the loins.

On one hand, the diffusion length of water and solutes involved in mass transport are supposed to affect the osmotic concentration behavior. Moreover, the rate of salt uptake by food diminishes when equilibrium between the concentration in the salt medium and the food matrix is attained [24]. Hence, the distinct behaviors of salt uptake observed in exterior and interior portions. In addition, the higher solid gain at/near the surface and consequent formation of a solute layer was probably the cause of decreased water loss in interior portions, due to a reduction of diffusion [24]. On the other hand, the results might also reflect the fact that frozen-thawed tuna was used herein, since the resultant flesh characteristics and cell structure affect salt diffusion [16,24].

Furthermore, the $\mathrm{pH}$ is expected to affect salting of fish via its effect upon ions $\left(\mathrm{Cl}^{-}\right)$diffusion and water loss and ultimately osmotic equilibrium [28] due to alterations in the selective permeability of cell membranes. The $\mathrm{pH}$ in fresh tuna determined in this study, 5.9-6.0, is consistent with published results [29,30]. Gallart-Jornet et al. [7] reports a pH of 5.8 in muxama; close to the values found herein. In contrast, Lã and Vicente [4] found that the $\mathrm{pH}$ of muxama from southeastern Algarve (Portugal) was 7.10, higher than that of fresh tuna (5.72), but the authors do not provide an explanation for that result.

We modeled the changes in the abovementioned physical-chemical parameters of tuna loins during the dry-salting stage of the production process using simpler and/or general equations (Table 1) than those published (e.g., [10]). In contrast, we decided not to model the changes observed in the values of color parameters considering the observed variability but values of $L^{*}$ and $a^{*}$ decreased in interior portions of loins while remaining relatively constant in exterior portions and chroma and saturation peaked after $12-16 \mathrm{~h}$ of drying.

In Experiment II, we studied the drying stage of the traditional process of muxama production. The values of moisture content and $\mathrm{a}_{\mathrm{W}}$ obtained at the end of the drying stage, particularly for loins dried for 7 days at $20{ }^{\circ} \mathrm{C}$, are lower than values of moisture of muxamas reported by Lã and Vicente [4] and Gallart-Jornet et al. [7], 47-50 g.100 $\mathrm{g}^{-1}$, and aw measured by Gómez et al. [31] in samples of muxama from Spain, 0.851, and by Lã and Vicente [4] in muxamas from Vila Real de Santo António (southeast Algarve, Portugal), 0.79. Most likely, this was due to a relatively shorter/minimal desalting stage in our experiment that contributed to prolonging salt incorporation/water loss during the following drying stage. The relatively low aW contributes to stability of the product since it is expected to inhibit the development of a number of (pathogenic) microorganisms [28].

The removal of water and the continued penetration of the remaining salt during the drying trials contributed to significantly increase the $\mathrm{NaCl}$ content. The final $\mathrm{NaCl}$ concentration (in terms of $Z^{\mathrm{NaCl}}$ ) was in line with values reported by Lã and Vicente [4], approximately $10 \%$ (i.e., $Z^{\mathrm{NaCl}}$ of about 0.17 ), and by Gallart-Jornet et al. [7], 7-8 g.100 $\mathrm{g}^{-1}$ ( $\mathrm{Z}^{\mathrm{NaCl}}$ of $\left.0.13-0.14\right)$ for marketed muxamas.

In addition, color changes were readily visible during the drying of loins. The changes were expressed as significant differences found in $\Delta \mathrm{E}$ and chroma/saturation values among treatments. The values of $\Delta \mathrm{E}$ calculated herein are greater than 2.3, a value stated as the just noticeable difference [32]. Seemingly, these composite color parameters reflected the changes in $L^{*}$ but not in $\mathrm{a}^{*}$. The color changes might be the result of browning reactions taking place in association with water removal thru drying and lipid oxidation favored by $\mathrm{NaCl}$. Notwithstanding, according to EU Implementation Regulations 2015/2110 and 2016/199 [1,2], muxama is expected to be dark brown on the outside and deep red on the inside. When cut, it shows varying darker shades at the edges. 


\section{Materials and Methods}

Tuna loin replicates $(30 \times 30 \times 100 \mathrm{~mm}$, Figure 5) mimicking the parallelepiped-shape and size-proportion of actual tuna loins were used herein. These loins were prepared from fresh tuna (Thunnus sp.) loins acquired at the fish market in Faro (Algarve, Portugal) and frozen using a blast and fluid bed freezer (Armfield Ltd., Ringwood, England) until core temperature reached $-20^{\circ} \mathrm{C}$. Before each experiment, stored frozen loins were thawed (overnight) in air inside a walk-in cooler at $4{ }^{\circ} \mathrm{C}$ until a core temperature of $0^{\circ} \mathrm{C}$ was attained.

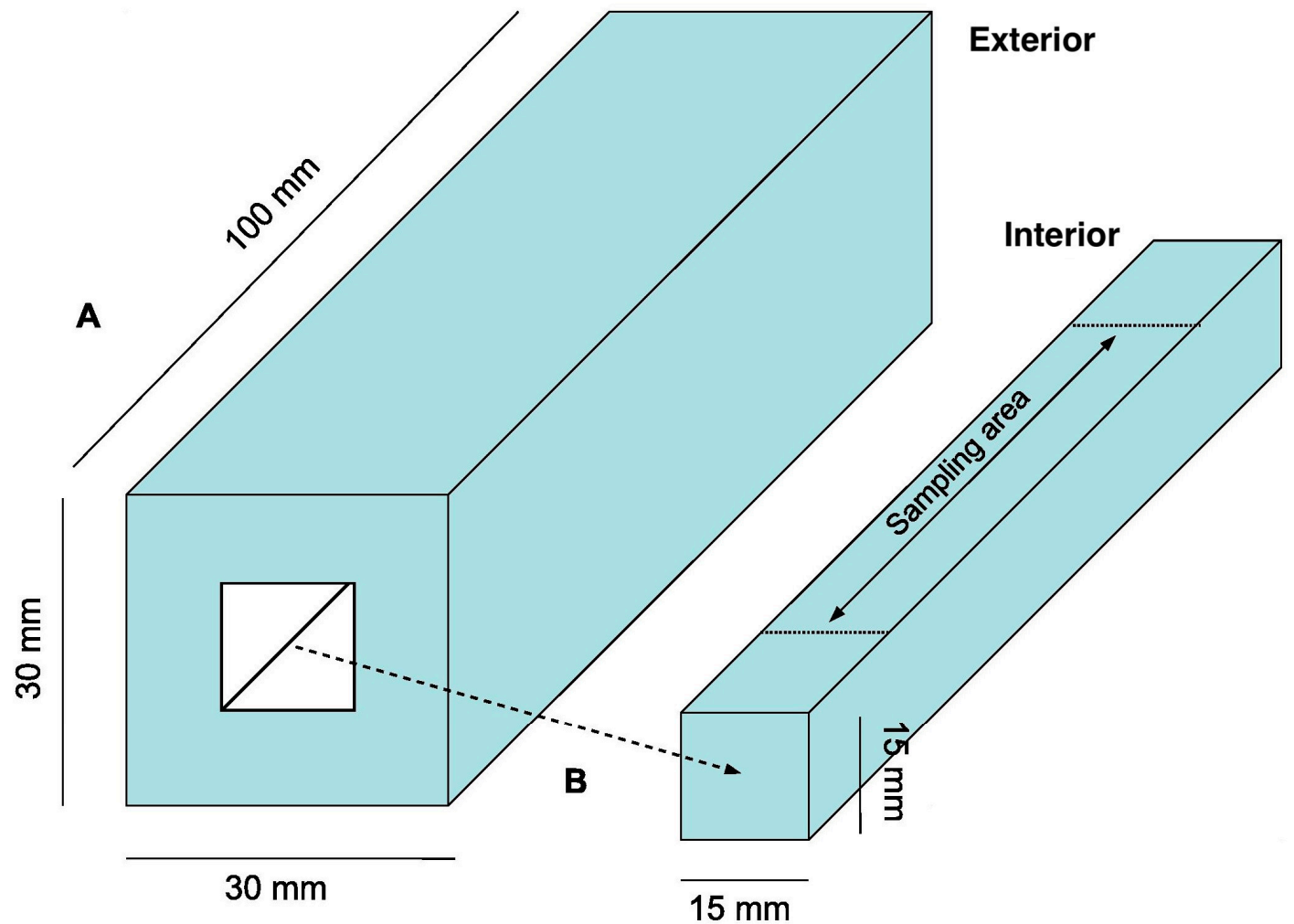

Figure 5. Illustration of the size and shape of the tuna loins used in the salting-drying experiments carried in this study. In Experiment I, (A) exterior and (B) interior portions of the loins were sampled and analyzed whereas complete loins were used in Experiment I. See main text for further details.

Two distinct, successive experiments were carried out, each conducted once with $n=2$ per sampling time. Experiment I: To study the dynamics of salting, ten loins were stacked in alternating layers of fish and solid salt $(1: 1 \mathrm{w} / \mathrm{w})$ in a polystyrene box for up to $24 \mathrm{~h}$. Two loins were sampled at the start of the experiment $(0 \mathrm{~h})$ and after 2.5, 5, 10 and $24 \mathrm{~h}$ of dry-salting. From each loin, the inner, center portion was separated from the outer, exterior section (Figure 5). The concentration of $\mathrm{NaCl}$, the $\mathrm{a}_{\mathrm{W}}$, moisture content $\left(\mathrm{g} \cdot 100 \mathrm{~g}^{-1}\right)$ and $\mathrm{pH}$ were determined for the two portions (in duplicate) using respectively, a chlorides-selective probe (Crison, Barcelona, Spain) connected to a potentiometer (Crison), an $\mathrm{a}_{\mathrm{W}}$-meter (Rotronic HygroLab 3, Bassersdorf, Switzerland), and a $\mathrm{pH}$-meter (Crison). $\mathrm{NaCl}$ concentration was handled herein as water-phase salt concentration, $Z^{\mathrm{NaCl}}=X^{\mathrm{NaCl}} /\left(X^{\mathrm{NaCl}}+X^{\mathrm{W}}\right)$ where $X^{\mathrm{NaCl}}$ is the concentration of $\mathrm{NaCl}\left(\mathrm{g} \cdot 100 \mathrm{~g}^{-1}\right)$ and $X^{\mathrm{W}}$ is the moisture content $\left(\mathrm{g} \cdot 100 \mathrm{~g}^{-1}\right)$, because salt content is meaningful for sensory perception and to favor (deleterious) enzymatic or bacterial reactions when in solution [16,33]. Moreover, color measurements (6 per loin) were carried out directly on the samples using a tri-stimulus colorimeter (Hach Lange Spectro-Color, Dusseldorf, Germany) and the CIE L*a* ${ }^{*}$ color scale (Commission Internationale de 
l'Éclairage CIE, Vienna, Austria). Composite color descriptors, color difference $(\Delta \mathrm{E})$, chroma $(\mathrm{C})$, saturation $\left(\mathrm{S}_{\mathrm{ab}}\right)$ and Hue angle $\left(\mathrm{H}_{\mathrm{ab}}\right)$, were derived from CIE $\mathrm{L}^{*} \mathrm{a}^{*} \mathrm{~b}^{*}$ parameters $[32,34]$.

Experiment II: To study the drying stage of muxama production, loins were stacked in alternating layers of fish and solid salt $(1: 1 w / w)$ in a polystyrene box for $24 \mathrm{~h}$ and then hanged to dry in a Fitoclima S600 chamber (aralab, Rio de Mouro, Portugal) at a relative humidity of $60 \%$ with controlled temperature $\left(14\right.$ and $\left.20^{\circ} \mathrm{C}\right)$ for 4 or 7 days. Moisture content $\left(\mathrm{g} \cdot 100 \mathrm{~g}^{-1}\right), \mathrm{a}_{\mathrm{W}}, \mathrm{NaCl}$ content and color were determined in two loins sampled at the start ( $0 \mathrm{~h}$, fresh), after dry salting ( $24 \mathrm{~h}$, salted) and at the end of the experiment ( 4 or 7 days) for each of the two temperatures tested ( 14 and $20^{\circ} \mathrm{C}$ ). The $\mathrm{NaCl}$ content was considered herein as $\mathrm{Z}^{\mathrm{NaCl}}$ and as the ratio of $\mathrm{NaCl}$ incorporation during drying, $R^{\mathrm{NaCl}}=X^{\prime \mathrm{NaCl}} / X_{\mathrm{S}}^{\prime \mathrm{NaCl}}$, where $X^{\prime \mathrm{NaCl}}$ is the concentration of $\mathrm{NaCl}\left(\mathrm{g} \cdot 100 \mathrm{~g}^{-1}\right.$ dry basis) at the end of drying and $X_{\mathrm{S}}^{\prime \mathrm{NaCl}}$ is the moisture content $\left(\mathrm{g} \cdot 100 \mathrm{~g}^{-1}\right.$ dry basis) after $24 \mathrm{~h}$ salting.

The changes in physical-chemical parameters, namely moisture, $\mathrm{a}_{\mathrm{W}}, \mathrm{pH}$ and color parameters, along the salting process (Experiment I) were modeled using appropriate functions via standard non-linear least squares procedures [35] and goodness of fit was assessed using pseudo- $\mathrm{R}^{2}$, $R^{2}=1-S S E / S S T$, where SSE is the sum of squared residuals and SST is the (corrected) total sum of squares. Randomness and normality of residuals was tested using runs and Shapiro-Wilk tests, respectively. Model selection was based upon Akaike's Information Criterion (AIC) [36,37]. In Experiment II, the results were analyzed using ANOVA in the context of a 2-level factorial experimental design with factors temperature $\left(14\right.$ and $\left.20^{\circ} \mathrm{C}\right)$ and time $(4$ and $7 \mathrm{~d})$. Predictive, regression-like equations were derived from ANOVA and their usefulness assessed by computing adjusted- and predicted- $R^{2}$. Statistical procedures were carried out at the 0.05 level of significance using package nlstools [38] in R [39] for the modeling approach and Design-Expert for Windows (Stat-Ease Inc., Minneapolis, USA) for experimental design and analysis.

\section{Conclusions}

We modeled the changes in physical-chemical parameters of tuna loins along the dry-salting stage (in Experiment I) using simple or general equations. Moreover, after Experiment II we were able to derive predictive equations that can be used to estimate the parameters of interest (moisture, $\mathrm{a}_{\mathrm{W}}, \mathrm{Z}^{\mathrm{NaCl}}$ and color-except for $\mathrm{a}^{*}$ and $\mathrm{H}_{\mathrm{ab}}$ ) by plugging in values of temperature and time in the appropriate range (Table 2). The lowest values of moisture and $\mathrm{a}_{\mathrm{W}}$ and highest $\mathrm{Z}^{\mathrm{NaCl}}$ were obtained after drying tuna loins for seven days at $20^{\circ} \mathrm{C}$ but they exceed the values reported for commercial products, 35-50\% relative moisture, aw around 0.89 and $\mathrm{Z}^{\mathrm{NaCl}}$ of 0.12 [7], and have impact in the appearance (color) of the product. A relatively short/minimal desalting stage and longer drying period at higher temperature likely contributed to prolonging salt incorporation/water loss. Thus, lower drying temperatures (about $14{ }^{\circ} \mathrm{C}$ ) are probably more appropriate. The results obtained in this study show a good chance of being successfully used in the design of future experiments at other conditions and assessing other quality parameters, e.g., total volatile base nitrogen (TVB-N), thiobarbituric acid reactive substances (TBA-RS), abundance of microorganisms and sensory attributes, as well as subsequent validation trials.

Supplementary Materials: The following are available online at www.mdpi.com/2410-3888/3/1/3/s1, muxama1.csv: dataset of experiment I, muxama2.csv: data set of experiment II.

Acknowledgments: Teresa Cavaco helped in the salting experiment. This study received national funds from FCT_Foundation for Science and Technology (Portugal) through project UID/Multi/04326/2013 (E.E.) and grant UID/MAR/00350/2013 (J.A.).

Author Contributions: E.E. and J.A. conceived, designed and carried out the experiments, analyzed the data and wrote the paper.

Conflicts of Interest: The authors declare no conflict of interest. 


\section{References}

1. European Commission. Commission Implementing Regulation (EU) 2015/2110 of 12 November 2015 entering a name in the register of protected designations of origin and protected geographical indications [Mojama de Barbate (PGI)]. In Official Journal of the European Union, L 306; Eur-Lex: Brussels, Belgium, 2015; pp. 1-2.

2. European Commision. Commission Implementing Regulation (EU) 2016/199 of 9 February 2016 entering a name in the register of protected designations of origin and protected geographical indications (Mojama de Isla Cristina (PGI)). In Official Journal of the European Union, L 39; Eur-Lex: Brussels, Belgium, 2016; p. 1.

3. The European Parliament and the Council of the European Union. Regulation (EU) No. 1151/2012 of the European Parliament and of the Council of 21 November 2012 on quality schemes for agricultural products and foodstuffs. In Official Journal of the European Union, L 343; Eur-Lex: Brussels, Belgium, 2012; pp. 1-29.

4. Lã, A.; Vicente, L. O Atum Esquecido; Universidade do Algarve: Algarve, Faro, 1993.

5. Yubero, I.D. Sabores de Andalucía. Distrib. Consum. 2008, 101, 116-125.

6. Aníbal, J.; Esteves, E. Muxama and estupeta: Traditional food products obtained from tuna loins in South Portugal and Spain. In Traditional Food Products: General and Consumer Aspects; Kristbergsson, K., Oliveira, J., Eds.; Springer: New York, NY, USA, 2016; pp. 271-274.

7. Gallart-Jornet, L.; Roberto, I.E.; Maupoei, P.F. La Salazón de Pescado, una Tradición en la Dieta Mediterránea; Editorial de la Universidad Politécnica de Valencia: Valencia, España, 2005; ISBN 8497059182.

8. Godinho, M. A Muxama. Available online: http://www.projectotasa.com/2011/01/a-muxama/ (accessed on 15 January 2015).

9. Esteves, E. Fish products from south Portugal: Dried litão, tuna muxama, and canned mackerel. In Mediterranean Food: Composition and Processing; Cruz, R.M.S., Vieira, M., Eds.; CRC Press Inc.: Boca Raton, FL, USA, 2016; pp. 65-101.

10. Barat, J.M.; Grau, R. Thawing and salting studies of dry-cured tuna loins. J. Food Eng. 2009, 91, 455-459. [CrossRef]

11. Rebelo, M.J.F. As Indústrias da Pesca e Conservas de Atum no Algarve do Século XX; Universidade de Algarve: Algarve, Faro, 2010.

12. Doe, P.E. Fish Drying \& Smoking: Production and Quality; Technomic Publishing Company, Inc.: Lancaster, UK, 1998; ISBN 9781566766685.

13. Van Nguyen, M.; Arason, S.; Eikevik, T.M. Drying of Fish. In Seafood Processing: Technology, Quality and Safety; Boziaris, I.S., Ed.; John Wiley \& Sons, Ltd.: Chichester, UK, 2014; pp. 161-175.

14. Doe, P.E.; Olley, J. Drying and dried fish products. In Seafood: Resources, Nutritional Composition, and Preservation; Sikorski, Z.E., Ed.; CRC Press Inc.: Boca Raton, FL, USA, 1990; pp. 125-145.

15. Graiver, N.; Pinotti, A.; Califano, A.; Zaritzky, N. Mathematical modeling of the uptake of curing salts in pork meat. J. Food Eng. 2009, 95, 533-540. [CrossRef]

16. Albarracín, W.; Sánchez, I.C.; Grau, R.; Barat, J.M. Salt in food processing; usage and reduction: A review. Int. J. Food Sci. Technol. 2011, 46, 1329-1336. [CrossRef]

17. Barat, J.-M.; Pérez-Esteve, E.; Aristoy, M.-C.; Toldrá, F. Partial replacement of sodium in meat and fish products by using magnesium salts. A review. Plant Soil 2013, 368, 179-188. [CrossRef]

18. Bellagha, S.; Sahli, A.; Farhat, A.; Kechaou, N.; Glenza, A. Studies on salting and drying of sardine (Sardinella aurita): Experimental kinetics and modeling. J. Food Eng. 2007, 78, 947-952. [CrossRef]

19. Boudhrioua, N.; Djendoubi, N.; Bellagha, S.; Kechaou, N. Study of moisture and salt transfers during salting of sardine fillets. J. Food Eng. 2009, 94, 83-89. [CrossRef]

20. Jain, D.; Pathare, P.B. Study the drying kinetics of open sun drying of fish. J. Food Eng. 2007, 78, 1315-1319. [CrossRef]

21. Oliveira, H.; Pedro, S.; Nunes, M.L.; Costa, R.; Vaz-Pires, P. Processing of Salted Cod (Gadus spp.): A Review. Compr. Rev. Food Sci. Food Saf. 2012, 11, 546-564. [CrossRef]

22. Sobukola, O.P.; Olatunde, S.O. Effect of salting techniques on salt uptake and drying kinetics of African catfish (Clarias gariepinus). Food Bioprod. Process. 2011, 89, 170-177. [CrossRef]

23. Wang, Y.; Zhang, M.; Mujumdar, A.S. Trends in Processing Technologies for Dried Aquatic Products. Dry. Technol. 2011, 29, 382-394. [CrossRef] 
24. Rahman, M.S. Osmotic dehydration of foods. In Handbook of Food Processing; Rahman, M.S., Ed.; CRC Press Inc.: Boca Raton, FL, USA, 2007; pp. 433-446, ISBN 9781845697587.

25. Arason, S.; Van Nguyen, M.; Thorarinsdottir, K.A.; Thorkelsson, G. Preservation of Fish by Curing. In Seafood Processing: Technology, Quality and Safety; Boziaris, I.S., Ed.; John Wiley \& Sons, Ltd.: Oxford, UK, 2014; pp. 129-160.

26. Zugarramurdi, A.; Lupín, H. A model to explain observed behavior on fish salting. J. Food Sci. 1980, 45, 1305-1311. [CrossRef]

27. Crawley, M.J. The R Book, 2nd ed.; John Wiley \& Sons, Ltd.: Chichester, UK, 2013; ISBN 9780470973929.

28. Hall, G.M. Fish. Processing; Wiley-Blackwell Publishing Ltd.: Chichester, UK, 2011; ISBN 9781405190473.

29. Monteiro, M.L.G.; Mársico, E.T.; Vital, H.C. Avaliação físico-química dos efeitos da irradiação e da evisceração na conservação de atum (Thunnus atlanticus) refrigerado. [Physicochemical evaluations of the effects of irradiation and evisceration on the conservation of refrigerated blackfin tuna (Thunnus atlanticus)]. Rev. Port. Ciênc. Vet. 2010, 105, 45-48.

30. Bernardi, D.C.; Mársico, E.T.; Freitas, M.Q. De Quality Index Method (QIM) to Assess the Freshness and Shelf Life of Fish. Braz. Arch. Biol. Technol. 2013, 56, 587-598. [CrossRef]

31. Gómez, R.; Carmona, M.; Fernández-Salguero, J. Estudio de los alimentos de humedad intermedia españoles. I. Actividad del agua y pH. In II Jornadas Científicas Sobre "Alimentación Española"; RACVAO: Jaen, Spain, 1991; pp. 124-130.

32. Sharma, G. Digital Imaging Handbook; CRC Press Inc.: Boca Raton, FL, USA, 2003; ISBN 978-1-4200-4148-4.

33. Gallart-Jornet, L.; Barat, J.M.M.; Rustad, T.; Erikson, U.; Escriche, I.; Fito, P. A comparative study of brine salting of Atlantic cod (Gadus morhua) and Atlantic salmon (Salmo salar). J. Food Eng. 2007, 79, 261-270. [CrossRef]

34. Macdougall, D.B. Colour in Food Improving Quality; CRC Press Inc.; Woodhead Publ. Limited: Cambridge, UK, 2002; ISBN 978-1-85573-590-3.

35. Ritz, C.; Streibig, J.C. Nonlinear Regression with R; Springer: Berlin, Germany, 2008; ISBN 9780387096162.

36. Akaike, H. A new look at the statistical model identification. IEEE Trans. Automat. Contr. 1974, 19, 716-723. [CrossRef]

37. Burnham, K.K.P.; Anderson, D.R.D. Model Selection and Multimodel Inference: A Practical Information-Theoretic Approach, 2nd ed.; Springer: Berlin, Germany, 2002; Volume 172, ISBN 978-0-387-22456-5.

38. Baty, F.; Ritz, C.; Charles, S.; Brutsche, M.; Flandrois, J.-P.; Delignette-Muller, M.-L. A Toolbox for Nonlinear Regression in R: The Package nlstools. J. Stat. Softw. 2015, 66, 1-21. [CrossRef]

39. R Core Team. R: A Language and Environment for Statistical Computing; R Foundation for Statistical Computing: Vienna, Austria, 2017; ISBN 3-900051-07-0.

(C) 2018 by the authors. Licensee MDPI, Basel, Switzerland. This article is an open access article distributed under the terms and conditions of the Creative Commons Attribution (CC BY) license (http://creativecommons.org/licenses/by/4.0/). 